\title{
ACCELERATING ADVISORY OPINIONS: CRITIQUE AND PROPOSAL
}

\author{
By Michael Reisman *
}

\section{Festina lente}

Time is a fundamental component of all social organization. Any component may be manipulated to achieve preferred outcomes, but time is particularly malleable. The concept of linear time, which allows complex sequential and conditional planning and deferred allocation of resources, is a critical part of Western political theory, for it facilitates the extension of present control far into the future. ${ }^{1}$ A peculiar genius of the law has been the elaboration of this linearism and the manipulation and supervision of different phases of future activity. Manipulation of time in mundane legal activities has a utility per se in that it permits order and efficiency in the complex, adversarial, but necessarily collaborative operations of groups and individuals. ${ }^{2}$ It is also a prerequisite to the realization of many other procedural privileges; without "enough" time, the privileges may be meaningless and even taunting.

- Of the Board of Editors. This article is a chapter of a work in progress, entitled "Six Studies in Procedural Pathology: A Critique of the Work of the International Court of Justice." It has benefitted from discussions with Myres McDougal. In addition, Philip Jessup and Leo Gross made many searching criticisms and a number of suggestions, some of which have been incorporated. The Table in the Annex was designed by James Malysiak, Yale J.D. 1973.

${ }_{1}$ See generally L. Mumfrord, Technics and Civmtzation 16, 42, 272 (1934, 1963).

2 The Kantian notion that time, though not a thing in itself, is an immutable part of the mind is increasingly rejected. The more relativist position, as developed, for example, by von Bertalanffy, is that time schema are a product of varying biological and cultural factors: von Bertalanffy, An Essay on the Relativity of Categories, 243, 22 Phu. of Sctence 243 (1945); reprinted in General Systems 71 (1962). See also SIFFRE, BEYOND TIME (1964) for reports of dramatic experiments in this regard. For a psychoanalytical critique, see Brown, LIFE AGAINST DEATE 272-75 (1959, paperback ed. 1970).

The most refined and articulated use of the time artifact in law is found in the common law's development of future interests, on which there is an enormous literaturc. Social scientists have been much concerned with "total control" situations in which an effective elite may organize social time in order to contribute to securing whatever the elite determines to be major institutional goals. Hence time-budget studies and time and motion studies for industrial settings, timetables for hospitals and prisons and so on. See J. Rotr, Themables: Structuring the Passage of Tame in Hospitar TreatMENT AND OTHER CAREERS (1963). For discussion and literature on time as a pervasive component of social organization, see J. Goody, Time: Social Organization, 16 I.E.S.S. 31- 11 (1968). For a survey of theories of time as factors in social change, see M. Heirich, The Use of Time in the Study of Social Change, Amer. Socrologrcar R. 386 (1954).

The manipulation of time may also have per se costs in terms of biological and psychological integrity. For some discussion, see the interesting speculative article by Wiegele, Toward a Psychophysiological Variable in Conflict Theory, 1 Expermenestar STUDY OF PoLTtrcs 51 (1971). 
A subtle aspect of adjudicative procedure is the design and implementation of the temporal sequences in which litigation takes place. I will refer generally to this manipulation of time as "temporal procedures." Temporal procedures have rationales. They are designed and refined by practice to maximize the efficiency of decisions and the skill of litigants and court in standardized contexts. Variations from these procedures can be evaluated in terms of their costs and their gains.

\section{The International Court's Tme Design}

With comparatively few meaningful guidelines from the Statute and the Rules of Court, ${ }^{3}$ the International Court of Justice plays a major role in designing the time sequences of different phases of adjudication. Its contemporary role can thus be compared with that of common law courts before the codification of rules of procedure and, in particular, the establishment of formal time limits for sequences of the judicial process. ${ }^{4}$ But the analogy cannot be pressed too far. For centuries common law courts have not had to depend upon the consent of the litigants in order to secure jurisdiction. To a great extent international tribunals must concern them-

${ }^{3}$ Statute Article 29 establishes a chamber of five judges "with a view to the speedy dispatch of business." Article 41, dealing with interim measures, is premised on the need for speed in certain cases. Article 43 confirms the Court's authority to fix time limits, and Article 48 confirms its more general procedural authority. Article 52 authorizes the Court to refuse to accept belated evidence, after the time limits it has set have expired. Article 61 limits the Court's revisory capacity to six months from the date of a new fact becoming known, but in no case more than ten years from the date of judgment.

Rules of Court Articles 36 and 37 (revised 1972) require the Registrar to transmit notice of application "forthwith" and the desire for expedition is found again in Article 38 ("as soon as possible"). Articles 40 and 41 (discussed infra) treat the setting of time linits. Article 53 authorizes the President of the Court to decide postponement only if the parties do not agree on the point. Rule Article 52, dealing with belated adduction of evidence, is somewhat narrower than Statute Article 52, for it seems to self-deny the Court's statutory power to refuse belated adduction even semble if the parties agree thereto. Article 53 refers to prior notification to the Registry of evidence a party intends to bring ("in sufficient time before the commencement of the oral proceedings"). Article 56 asks that oral statements be "as succinct as possible." Presumably Articles 53 and 56 are hortatory; no sanctions are designated. Article 69 dealing with interventions by third-parties requires that they be taken no later than the conmencement of the oral proceedings. Article $76(4)$, dealing with Chambers, requires the President to convene it "at the earliest date compatible with requirements of the procedure," and Article 77 is somewhat more peremptory in regard to the Chamber's competence to set time limits.

Article 87 of the Rules states that an accelerated procedure will be followed when the requesting agency indicates or the Court concludes that urgency is called for. For doctrinal treatment, see L. Gross, The Time Element in the Contentious Proceedings of the International Court of Justice, $63 \mathrm{AJIL} 74$ (1969); on the more technical problem of computation, see Deák, Computation of Time in International Law, 20 AJIL 502 (1926).

- See, for example, Rule 6, Federal Practice Rules (1971). 
selves with this problem. Hence their ambit of discretion, in dealing with time as in other matters, is constrained by the quantity of effective power that they believe components of the world community will deploy to support their decisions. And common law systems do not generally provide for an advisory jurisdiction. ${ }^{5}$ In international advisory cases, the ICJ may assume a public role greater than that of the domestic tribunal in ordinary litigation of the meum and tuum of municipal life. In this article, our focus is primarily the advisory jurisdiction of the Court. Where appropriate, experience will be drawn from the contentious jurisprudence of the Court. Some of the recommendations developed will be applicable to both jurisdictions. Since both contentious and advisory jurisdictions produce choices that affect the political process, the term "decision" will be used

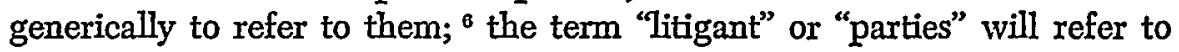
actors who address the Court.

The manipulation of time in international tribunals may have great impacts on the case at bar and the community. In certain circumstances, the time element is critical for a major or ancillary issue. Where the subject of litigation is a res quae usu tolluntur, the speed of the decisionmaking process must seek to surpass the speed of the consumption of the object at issue. Where the issue concerns a seasonal industry, such as fishing, shortening time may be important as a way to minimize the losses of that party which may be vindicated in the suit or, at least, to provide it with an earlier opportunity to shift its resources into other areas to lessen future loss. ${ }^{7}$ Speed may also be necessary if a major international institution must postpone a decision until an advisory opinion is issued. Judge Jiménez de Aréchaga believes that, "a request for an advisory opinion normally implies a postponement of a decision on the merits by the requesting organ until the answer has been received." 8 But postponement of a decision does not dictate speed of adjudication; indeed, reference to the Court for an opinion may be a device to buy or to waste time.

A number of procedures are available to litigants who concur in the need

5 The Judicial Committee of the Privy Council is, to all intents and purposes, a contentious appeal instance. The prominent common law exception is the Canadian "Reference" power and its analogues in Canadian provincial legislation. Supreme Court Act, R.S.C. 1952, c. 259, s.55. See generally Strayer, Judrotar, Review of LegisLATION In CaNAda 189 ff. (1968). Cf. U.S. Constitution, Article 3(1). For one recent construction, see Sierra Club v. Morton, 92 S.Ct. 1361 (1972). On the broader function of advisory jurisdiction, see Hudson, Permanent Court of Internationar JUSTICE 523-24 (1942).

o See generally Rersman, Nulurty and Reviston 157-59 (1971). Barberis has noted in this regard that both the Permanent Court and the International Court have mentioned opinions and decisions as precedents indistinguishably. See J. A. Barberis, La Jurisprudencia Internacional como fuento de Derecho de Gentes según la Corte de la Haya, 31 ZAöRV 641, 667 (1971).

'See, for example, Fisheries Jurisdiction, case, [1972] ICJ REp. 35. But of. the Court's refusal to accelerate procedure to take account of the seasonal requirements of the British fishing industry: Anglo-Norwegian Fisheries Case, Order [1951] ICJ REp. 9.

$8 \mathrm{Jjmen} n e z$ de Aréchaga, The Amendments to the Rules of Procedure of the International Court of Justice, 67 AJIL 1, 9 (1973). 
for expediting the process: a chamber of summary procedure, ${ }^{9}$ the device of stipulation of either facts or principles of law, ${ }^{10}$ and even prior agreements on time limits. But it is the Court which is magister temporis, the major architect in shaping the temporal dimension in each case. Article 48 of the Statute provides:

The Court shall make orders for the conduct of the case, shall decide the form and time in which each party must conclude its arguments, and make all arrangements connected with the taking of evidence.

Article 40 of the Rules, as revised, ${ }^{11}$ illuminates the general power of the Court to conduct hearings as set out in Statute Article 48. Rule 40 provides:

1. In every case submitted to the Court, the President will ascertain the views of the parties with regard to questions of procedure; for this purpose he may summon the agents to meet him as soon as they have been appointed.

9 See Art. 26 to 29 of the Statute of the Court and Art. 24 to 27 of the Rules of Court.

10 Note, however, that stipulations prearranged by the parties probably do not bind the International Court of Justice, the preeminent role of the compromis in a system of consensual jurisdiction notwithstanding. Jura novit curia. Thus, in Coleann c. Etat Allemand, 9 R.D.T.A.M. 216, the Mixed Tribunal would not hold itself bound by party preagreement on certain points. In a dissent in the Oscar Chinn case, Judge Schücking contended that the terms of Statute Article 38 obliged the Court to ignore treaties stipulated by the litigants if the Court knew that the treaties were invalid. [1934] PCIY ser. A/B No. 63, at 149-50. An analogy to stipulated but incorrect facts would be compelling, although the ICJ might well provide an opinion on preagreed "hypothetical" facts which could be of use to the litigants, for example in establishing ex nihilo a complex treaty regime. Some precedent for this type of activity might be found in the Namibia case itself; there the Court advised all states of the lawfulness of different types of projected behavior which was not yet commenced or consummated in occupied South West Africa: [1971] ICJ REP. 16, 54-57. In the Monetary Gold case, the International Court seems to have rejected the options which the parties to the Washington Agreement proposed, although the reasons for the Court's choice in this complex and baflling decision are not clear: [1954] ICJ REP. 19. On the other hand, in the Minquiers and Ecrehos case, [1953] ICJ REP. 47, the Court accepted compromissary options which, according to one scholar, obliged the Court to assume that either France or the United Kingdom owned the islets and excluded the possibility of condominium or tes nullius: Rocme, Tre MINquiners and Ecrenos Case: AN ANalysis of the Deciston of the Interinatronal Court of Justice 49 ff. (1959). An important factor in the lawfulness of these preagreements would seem to be the extent to which they infringed rights of third parties. Thus in Minquiers and Ecrehos, compromissary preagreement which precluded a decision confirming that the existence of a condominium would be lawful, for it would affect only the litigants themselves. I would suggest that the same pattern of reasoning be applied to problems of determining lawfulness of time stipulations: Does the subject matter of the case and the effect of acceleration affect only the litigants themselves or does it also affect others, outside of the judicial arena? For other criteria for such decisions, see infra at pp. 17-23. See also ReIsalan, supra note 6, at 54I-54.

11 The Rules, as amended on May 10, 1972, are published in ICJ Acrs AND DocuMENTs, No. 2, and in 67 AJIL 195 ff. (1973). Background material is found in Jiménez de Aréchaga, supra note 8. 
2. In the light of the information obtained by the President, the Court will make the necessary orders to determine, inter alia, the number and the order of filing of the pleadings and the time-limits within which they must be filed.

3. In making an order under paragraph 2 of this Article, any agreement between the parties which does not cause unjustified delay shall be taken into account.

4. The Court may, at the request of the party concerned, extend any time-limit, or decide that any step taken after the expiration of the time-limit fixed therefor shall be considered as valid, if it is satisfied that there is adequate justification for the request. In either case the other party shall be given an opportunity to state its views.

5. If the Court is not sitting, its powers under this Article shall be exercised by the President, but without prejudice to any subsequent decision of the Court. If the consultation referred to in paragraph 1 of this Article reveals persistent disagreement between the parties as to the application of Article 44, paragraph 2, or Article 45, paragraph 2 , of these Rules the Court shall be convened to decide the matter.

Article 52 of the Statute gives the Court a limited policing power over some temporal sequences of procedure.

After the Court has received the proofs and evidence within the time specified for the purpose, it may refuse to accept any further oral or written evidence that one party may desire to present unless the other side consents.

As is characteristic of consensual jurisdiction, the Court cannot, it would seem, bar belated oral or written evidence if the other litigating party consents. ${ }^{12}$ If, however, the other party does not consent, the Court has discretion whether to permit belated adduction of evidence. The Court has on occasion acted contrary to the wishes of the parties in regard to setting and revising time limits. In the Asylum case, a postponement requested by one party and agreed to by the other was refused on the grounds of "good administration of justice." 13 Later, a request for postponement, opposed by one party, was granted by the Court. ${ }^{14}$ The Court has been forceful, if not quite as decisive, in time-limit matters in the

12 However, an arbitral tribunal, it would seem, might under certain circumstances, bar proprio motu such belated adduction despite the agreement thereto by the other litigant. If, for example, the tribunal concluded that the time limit of its compromis could be tolled if it did not close proceedings and undertake judgment, it might bar belated evidence. It is arguable that, in such circumstances, the opposing party's agreement to adduction of belated evidence is also a tacit extension of the temporal life of the compromis. However, with the lesson of the disruption of the Franco-Mexican Commission of 1924, an arbitrator would be prudent to bar belated adduction unless written agreement to temporal extension were given. 5 U.N.R.I.A.A. 512 (1929) and see Cartston, The Process of International Arbitration 47 (1946).

13 [1949] ICJ REP. 267.

14 [1950] ICJ REP. 125; in this case, the Court appears to have been moved by its own administrative exigencies. Among other reasons which the Court cited for its order, it noted the ". . . priority which the Court must give to other cases . . " ibid. 
Fisheries case ${ }^{16}$ and the Right of Passage case. ${ }^{16}$ Yet in contentious cases, the Court shares the competence to shape the time dimension with the litigants. Though the litigants may be responsible for the lethargy of proceedings, the Court often bears the blame. With some apparent exasperation, the International Court in the Barcelona Traction case, noted

the unusual length of the present proceedings, which has been due to the very long time-limits requested by the parties for the preparation of their written pleadings and in addition to their repeated requests for an extension of these limits. ${ }^{17}$

In separate opinions, Judges Fitzmaurice ${ }^{18}$ and Jessup ${ }^{19}$ commented even more acidly on the parties' tempo.

Because advisory procedures are less consensual, formally if not actually, in their jurisdictional basis, ${ }^{20}$ the Court's statutory authority to set and to police stringent time limits would seem even greater. Whereas the concurrence of "the other side" in contentious procedures forces the Court to extend a time limit to permit the adduction of belated oral or written evidence, the absence of an "other side" in advisory procedures would appear to give the Court a much freer hand in time control. And, indeed, Article 66 of Chapter IV of the Statute, entitled "Advisory Opinions," details the increased power of the Court, or, if not in session, the President, to set time limits. ${ }^{21}$

15 [1950] ICJ REP. 62.

10 [1958] ICJ REP. 40. A number of other cases are discussed in 2 Rosenne, The Law and Practice of the Internationat Court 559-62 (1965).

17 Case Concerning the Barcelona Traction Light and Power Company, Limited, [1970] ICJ REP. 4, 30-31.

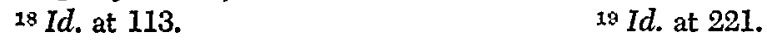

${ }^{20}$ Where the effectiveness of an advisory opinion depends upon the acquiescence of a state or states and the organ or agency requesting the opinion does not have the effective power to force the actual targets to comply, the Court encounters the same control considerations it ordinarily faces in contentious jurisdiction: see Reusncan, supra note 6, at 277-85. Thus in cases such as Certain Expenses [1962] ICJ REP. 151 and Namibia [1971] ICJ REP. 16 the effectiveness of the advisory opinion will depend upon preponderant superpower acquiescence and, in the latter case, acquiescence of South Africa. A comparable analysis can be applied in regard to the Peace Treaties case [1950] ICJ Ree. 65; 221.

21 Statute Article 66 provides:

1. The Registrar shall forthwith give notice of the request for an advisory opinion to all states entitled to appear before the Court.

2. The Registrar shall also, by means of a special and direct communication, notify any state entitled to appear before the Court or international organization considered by the Court, or, should it not be sitting, by the President, as likely to be able to furnish information on the question, that the Court will be prepared to receive, within a time limit to be fixed by the President, written statements, or to hear, at a public sitting to be held for the purpose, oral statements relating to the question.

3. Should any such state entitled to appear before the Court have failed to receive the special communication referred to in paragraph 2 of this Article, such state may express a desire to submit a written statement or to be heard; and the Court will decide.

4. States and organizations having presented written or oral statements or both shall be permitted to comment on the statements made by other states or organiza- 
The rubric "advisory" may conceal contention. Indeed, substantively contentious bilateral cases, such as the Nationality Decrees ${ }^{22}$ case, have been brought before the Permanent Court under advisory jurisdiction. ${ }^{23}$ In cases such as these, there is, in the language of Article 52, an "other side," whose consent to belated adduction might extend time limits without regard to the wishes of the Court. Where "contention" exists under the advisory jurisdiction of the Court, Article 68 of the Statute provides:

In the exercise of its advisory functions the Court shall further be guided by the provisions of the present Statute which apply in contentious cases to the extent to which it recognizes them to be applicable.

When there is an "other side," the Court ought to extend to it the peculiar procedural prerogatives which contentious adjudication vouchsafes. ${ }^{24}$ There are two reasons for this. First, these safeguards are part of the distinctive character of the judicial arena; compliance with notions of "fairness" is a component of the authority and ultimately the power of the Court. Second, without assurance of compliance with these safeguards, states are unlikely to lend the participation which is critical to the Court's effectiveness. In advisory as well as contentious cases, the Court must consider more than its own convenience and its own perspective of an appropriate time sequence, when time is, or is provisionally deemed to be, of the essence.

Even in those cases in which time is not of the essence, the Court must shape the time dimension in appropriate ways. The ICJ, with its present and projected docket, is unlike institutions such as domestic courts and

tions in the form, to the extent and within the time limits which the Court, or, should it not be sitting, the President, shall decide in each particular cose. Accordingly, the Registrar shall in due time communicate any such written statements to states and organizations having submitted similar statements.

22 PCIJ ser. B, No. 4, at 17.

28 The parties may be quite candid about the contentious, bilateral character of the "advisory opinion." See the speech by Sir Douglas Hogg before the Court, January $\theta$, 1922 PCIJ ser. C, Acts and Documents Relating to Judgments and Advisory Opinions Given by the Court, No. 2, Documents Relating to Advisory Opinion No. 4, Annex 2, at 17. Other transparently "contentious" advisory opinions have included Railway Traffic between Lithuania and Poland, PCIJ ser. A/B, No. 42, at 108; Javorzina Boundary. PCIJ ser. B, No. 8 , at 6.

24 The Court's actual response to advisory cases in which the guest of honor chose not to attend has varied, but has almost always indicated concern for the absence of consent. In the Status of Eastern Carelia case, the Permanent Court refused to render an opinion because the Soviet Union, in many senses the defendant, refused to consent or attend: [1923] PCIJ ser. B, No. 5 at 7, 27-29. In that case, the Soviet Union was not even a member of the League of Nations and hence could not be deemed to have undertaken either a general or collateral obligation to adjudicate differences. In the contentious Monetary Gold case [1954] ICJ ReP. 24, the Court rendered its decision in a way which, in effect, protected the interests of Albania, which was at that time not a member of the United Nations. The Monetary Gold case arose out of the failure of Albania to pay compensation due to the United Kingdom under the decision of the Court in the Corfu Channel case, [1948] IC] REP. 15; [1949] ICJ REP. 4; [1954] IC] Rep. 19. The Court had initially based its jurisdiction in the Corfu Channel case on the doctrine of forum prorogatum but in the subsequent proceedings jurisdiction was based on the special agreement concluded by the United Kingdom and Albania. 
hospitals which draw on resources insufficient for the problems and case loads each is assigned to process. Overloaded institutions develop operational codes ${ }^{25}$ for allocating scarce resources; actors within such institutions know almost intuitively how much to give to each case, and decisions are constantly made implementing and revising the code. Because time has not been an urgent institutional concern, the Court does not appear to have evolved a refined time code; ${ }^{26}$ the Court can afford to be more generous with its resources, to tailor the sequence of time to each case, but not to be prodigal. If there are not many other cases, there are other cases; and while one of the litigants may anticipate a gain in delay, particularly for negotiating purposes, a significant time lag may involve real deprivations for its opponent. And there may be debits of impaired perception and understanding involved in long delays and frequent interruptions as opposed to a fairly smooth and consecutive set of judicial sequences. ${ }^{27}$ It is thus no surprise that Article 41 of the Rules of Court states that “. . . time limits shall be as short as the character of the case permits." In regard to advisory opinions, Article 87(2) of the Rules provides that if "the Court finds that an early answer would be desirable, the Court shall take all necessary steps to accelerate the procedure."

But accelerated procedure, like its lethargic counterpart, also has its costs. Too stringent a control of the time element may impose hardships on one or more of the litigants and may in certain circumstances amount to the deprivation of a procedural right. Many procedural rights can be implemented only with sufficient time. Thus audi alterem partem is meaningful only if there is adequate time to prepare written and oral pleadings and to engage in the many other preadjudicative steps which must be performed if the promised day in court is to be exploited. Similarly the right to counsel is meaningful only if there is sufficient time to consult with counsel. Intergovernmental and crosscultural litigation may involve consumptions of time not comparable to those of municipal litigation. A case may involve major policy considerations requiring consultation of different departments and agencies in a government; such activities can extend the time necessary for the preparation of pleadings. Translation may require time. In the Anglo-Norwegian Fisheries case, Norway observed:

Le Gouvernement norvégien doit rediger son Contre-Mémoire en une langue étrangère et doit également faire traduire toute la documenta-

\footnotetext{
28 On operational code, see N. Letres, The Operattonal Code of tae Politburo (1951) and idem. A StUdY of Bolshevisar (1953). In Reisman \& Simson, Compacts: A Study of Interstate Agreements in the American Federal System 27 RutGers L. R. 70 (1973), operational code is used to designate the demands and related expectations actually held by politically relevant strata in an institutional setting. In a hospital setting, for example, where general social morality barred overt discussion of allocation of scarce resources for patients determining who will live, for how long, and who will die, the "operational code" would refer to the unwritten and unstated norms about making these decisions.

${ }^{28}$ But of. Order, Anglo-Norwegian Fisheries, [1951] ICJ REP. 9.

27 Indeed, the Court itself indicated some awareness of this feature in an Order on a time decision in the Anglo-Norwegian Fisheries case [1951] ICJ REP. 9.
} 
tion y jointe: il est obligé, enfin, de faire imprimer Contre-Mémoire et annexes hors de son pays. ${ }^{28}$

Linguistic parochialism does not correlate with the smallness of a state, but it seems certain that many smaller states lack the resources to secure quick and accurate translations of documents vital to the preparation of a case.

In these and similar cases, time may be so fundamental to the exploitation of a procedural right that, where a time deprivation effectively eviscerates it, there might be a ground for nullification. ${ }^{29}$

Certain claims to participate, which were formerly considered procedural rights, are now deemed, in municipal systems, to be primarily for the benefit of the tribunal. Thus, the extent of the right to be heard in administrative settings is often determined by the needs of the administrative organ for information regarding the pending decision. ${ }^{30}$ The policies that might support this view municipally have scant application in international adjudication where the extent of the privilege to present one's own case may be an important component in securing compliance with an adverse decision as well as in prospective consent to adjudicate. For an institution whose jurisdiction is consensual, too stringent a hand in shaping the time dimension of a case can drive off potential litigants.

\section{II}

\section{The Acceleration of the Nammia Case}

The Namibia case ${ }^{31}$ presents in sharp relief many of the problems involved in the judicial design of the temporal sequences of a case. The requesting resolution of the Security Council, adopted on July 29, 1970,32 asked that the advisory opinion ". . . be transmitted to the Security Council at an early date." The core text of the request was wired that day, and certified copies were sent by the Secretary-General to the Court, apparently through regular mails. They had not yet reached the Registry of the Court by August 5, 1970.33 On that day, the texts of the resolution in English and French were wired to the Court's Registry. ${ }^{84}$ On the same day, the President of the Court issued an Order, fixing September 23, 1970 as the

28 Anglo-Norwegian Fisheries, 4 Pleadings 637, cited in 2 RosenNe, supra note 16, at 561 .

29 See Domke, Israeli-Soviet Oil Arbitration, 53 AJIL 787 (1959). The statutes of international arbitral tribunals do not provide for nullifications of their own awards; the Statute of the ICJ is no exception to this practice. Regarding the possibility of nullification of an ICJ judgment see REISMaN, supra note 6, at 123-24; Reisman, Revision of the South West Africa Cases: An Analysis of the Grounds of Nullity in the Decision of July 18, 1966 and Methods of Revision, 7 VA. J. INr'L L. 1, 12-15 (1966).

30 See, for example, I Davis, Administrative Law Treatise 382, 412 ff. (1958). Cf. the comment of the Registrar of the ICJ in a cable to Professor Elias, implying that the O.A.U.'s right to submit a written statement in the Namibia case depended on the Court's independent conclusion that the O.A.U. could furnish information on the question. 2 Pleadings, Namibia 646 and see infra text and notes at note 49.

31 [1971] ICJ REP. 16. 32 Sec. Council Res. 284 (1970).

332 Pleadings, Oral Arguments, Documents, Namibia Case 629.

34 Ibid. 
time limit for written statements to be filed by members of the United Nations. ${ }^{35}$ On the same day, the Registrar sent the "special and direct" communication, required by Article 66 of the Statute, to "any state entitled to appear before the Court or international organization considered by the Court ... as likely to be able to furnish information on the question. ..." 36

The Order thus allowed fifty days, from day of issuance to day of closure, within which time states and specific international organizations might exercise their privilege to prepare and submit written statements. Only on August 21, 1970, did the President of the Court decide that nonmember states entitled to appear before the Court should also be sent the "special and direct" communication. ${ }^{37}$ Hence these states were initially allowed only 34 days from issuance of the invitation to closure to prepare and submit written statements.

In comparative quantitative terms, as the appended table shows, ${ }^{88}$ a fifty-day period in an accelerated case was not a noticeably shorter time limit for the submission of written statements than that allowed in an ordinary nonaccelerated case. However, it was, at least initially, significantly shorter than the time allowed in the two other opinions dealing with South West Africa. Comparison cannot be drawn with the contentious South West Africa cases of $1966,{ }^{39}$ for time limits there were regulated predominantly by the litigants themselves.

On August 19, 1970, the South African Secretary of Foreign Affairs formally requested an extension until January 31, 1971 of the time limit set by the President." The South African Government invoked "Rule of Court 37.4 read with Rule of Court 82.1." [Rule 37(4) is now Rule 40(4); Rule 82(1) is now Rule 87(1).] South Africa contended that it was the state most intimately concerned in the matter and that justice required that it be given a fair opportunity to present its views. It knew most about South West Africa and hence the Court would gain if South Africa were given sufficient time to adduce all the evidence it deemed relevant. A number of important issues were raised in the request, South Africa contended, and they could not be presented before January, 1971. South Africa conceded that the Security Council had asked for an early opinion but argued that "Rule of Court 82.2 should always be accompanied by a full regard for the requirements of justice." 41

The President of the Court acceded to South Africa's request only in part. He extended the time limit to November 19, 1970 or an additional 57 days. ${ }^{42}$ His Order was not accompanied by reasons. One would presume that this omission stemmed from the President's view that he was acting on the basis of a discretionary competence. It is clear from the Court's response to later procedural claims that it was unwilling to characterize South Africa as in any way an adversary, entitled pro tanto to the privileges available

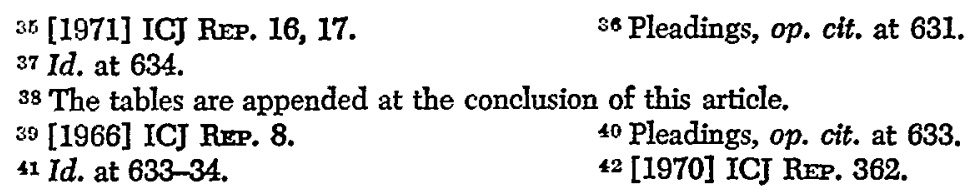


to litigants in contentious procedure. ${ }^{48}$ Nevertheless, it is with this particular order that some of the problems of accelerated procedure began to surface.

The time limit was proving a problem not only for South Africa. On November 13, 1970, the Permanent Representatives to the United Nations of Burundi, Nigeria, Sierra Leone, the United Arab Republic, and Zambia, wrote from New York to the Registrar that, in concert with certain other African states, they were preparing a joint written statement:

Our Governments very much regret, as do the other African Governments concerned, that it has not proved possible to complete this joint statement, relating to a most important subject on which a vast quantity of documentation exists, within the time limit of 19 November 1970 for the filing of written statements, .. . Our Governments are fully aware of the concern of the Court that it be permitted to proceed in any contentious case or advisory opinion with the utmost expedition, but our Governments wish to stress their very strong hope and desire that an extension may be granted to permit the African States concerned to file their joint written statement.

Our Governments trust that you fully appreciate the element of time involved in the preparation of a joint statement by a number of African Governments, owing to the process of consultations required in such a situation. ${ }^{41}$

On the same day, Professor T. O. Elias, Attorney General and Commissioner for Justice of Nigeria, wrote from Lagos to the Registrar, on his own and on behalf of Dr. Abdullah El-Erian of the U.A.R. Mission to the United Nations. Concerned that the request for an extension of the time limit would not be granted, he submitted what he described as a "hurried Memorandum on the subject." This was to be submitted on behalf of the Organization of African Unity, and a proof of authorization would follow in due course.ts

It was not until November 18 that the Registrar received a cable of the joint African request for an extension. ${ }^{40}$ The letter itself arrived only "late in the afternoon of 19 November 1970." 47 In a cable to Professor Elias on November 18, the Registrar stated:

President however is not disposed to grant any extension but intends to inform all recipients of special and direct communication that Court will be prepared to hear oral statements from them in the course of hearings ... . 43

Furthermore, cabled the Registrar, "Organization of African Unity was not considered by President as likely to be able to furnish information on question." 49 The OAU could still appeal the President's ruling to the plenary court, but only late in January. The Registrar stated, however, that the Elias Memorandum would be accepted if it were promptly certified as submitted for any one or any number of the five states on whose behalf

$48 \mathrm{Id}$. at 21-27.

$40 \mathrm{Id}$. at $642-43$.

47 Id. at 647 .

40 Id. at 646 .
14 Pleadings, op. cit. at 642 .

40 Id. at $645-46$.

$48 \mathrm{Id}$. at 645 . 
the request had originally been lodged.50 On November 20 , the Permanent Representative of Nigeria to the United Nations wired the Court that the Elias Memorandum was sponsored by the Federal Republic of Nigeria and it was so accepted by the Registrar. ${ }^{51}$ On November 24,1970 , the Registrar wrote the group of African states conveying in more extended form the gist of his telegram to Professor Elias. ${ }^{62}$ On the same date, the Registrar wrote to the Yugoslav Foreign Office accepting its Memorandum. The Registrar observed that

... le Président de la Cour a decidé de l’accepter bien qu'elle soit parvenue après la date d'expiration du delai pour le depôt des exposés écrits .....$^{3}$

Twelve states, only two of which were permanent members of the Security Council, submilted written statements; ${ }^{54}$ eight states, only one of which had not submitted a written statement, appeared in the oral proceedings. ${ }^{55}$ The United Nations Secretariat submitted a written statement and appeared for oral argument. ${ }^{58}$ The Organization of African Unity appeared in oral argument. ${ }^{67}$ In short, 13 states including two permanent members of the Security Council, the Secretariat, and one regional organization participated in a major international constitutional case before the International Court of Justice. If comparison takes into account the growing number of states competent to appear before the Court in an advisory case, ${ }^{58}$ then participation in this case shows a significant decline.

After closure for submission of written statements, the tempo of the case was less than frenetic. Oral statements were heard from February 8 to March 17, 1971. The advisory opinion was delivered on June 21, 1971, 97 days after closure of all proceedings. This 97 -day period seems to have been almost twice as long as the average interim between closure and opinion in unaccelerated advisory cases. ${ }^{59}$

While participation in other major constitutional cases has been far from plenary, it has somewhat exceeded participation in this case, if the denominator of participation is the number of member states competent to appear before the Court. ${ }^{60}$ Causal links between the time limits set by the Court and the decision by different foreign offlces to begin to prepare written

so 1 bid.

32 Id. at $647-48$.

BI Ibid.

ss Id. at $648-49$.

54 The states submitting written statements or letters were Czechoslovakia, Finland, France, Hungary, India, the Netherlands, Nigeria, Pakistan, Poland, South Africa, the United States, and Yugoslavia.

ss Finland, Nigeria and the United Arab Republic sub nom. the Organization of African Unity, the Netherlands, Nigeria, Pakistan, South Africa, Republic of Vietnam, and the United States.

so 1 Pleadings 75-206; C. H. Stavropoulos and D. B. H. Vickers pleaded orally for the Secretary-General.

672 Pleadings 88.

s8 If we take as a base the Reservations case of 1951 which also dealt with a world constitutive issue and in which there was the same number of participants as in the Namibia case, rough participatory comparisons are as follows: In 1951, 13 out of 60; in 1971,13 out of 130 . In short participation was about halved.

${ }^{89}$ See Annex, infra pp. 670-71.
${ }^{60}$ See supra note 58. 
statements are, perforce, speculative. With that caveat, I am assuming that the Court's decision as to time did deter certain states, at least as many as four African states, from preparing statements and, in general, acted to "chill" if not to still procedural privileges. The Court seemed to assume that the availability of oral argument would compensate for the inability to submit a timely written statement. ${ }^{61}$

Because the Statute and the Rules permit the Court to accelerate the advisory procedure when it is necessary, the mere fact that acceleration took place and that procedural privileges were proportionately reduced cannot be characterized per se as a procedural pathology. The critical question for the evaluator of lawfulness, as well as for the actual decisionmaker, is whether the chosen degree of acceleration and the corresponding diminution of procedural privileges were justified in the circumstances of the case.

\section{III}

\section{Criteria for Acceteration}

When a requesting organ indicates urgency, the decision to accelerate is exclusively a matter for the Court's competence. If the Court is not obliged to respond to a request for an advisory opinion, a matter which has been well established since the Eastern Carelia case, ${ }^{62}$ it is certainly not obliged to accept the characterization of urgency as set by the requesting agency. ${ }^{\text {es }}$

What then are the procedures and the criteria which the Court in particular, and institutions faced with the time problem in general, ought to apply in determining whether to accelerate and the degree of acceleration?

I suggest the following guidelines:

(1). Determine, by contextual investigation, the existence of a crisis and its magnitude, particularly with regard to the aggregate social and political consequences likely to ensue should judgment or opinion be rendered in the normal tempo.

(2). Determine the extent to which rapid decision will contribute to abating the crisis.

(3). Balance the gains in abatement of the crisis by acceleration of the process against the costs in diminution of participation which may be a consequence of acceleration.

(4). Gauge the extent to which the case at bar is one of major world constitutional concern. Seek to increase participation in such decisions in proportion to the constitutional magnitude of the case.

(5). Where rapid decision is necessary, seek innovative ways of freezing events or restraining that behavior the projected consummation of which

612 Pleadings 648.

62 [1923] PCIJ ser. B, No. 5.

${ }^{88}$ As Judge Jiménez de Aréchaga has observed (supra note 8, at 9):

Naturally the requesting organ only expresses its view and its desire as to the urgency of the answer: it remains for the Court to comply with this request if it is feasible to do so, taking into account all of its duties and functions. 
has elicited a demand for acceleration, rather than obliging judges and litigants to accelerate their own activities and deliberations.

Let us consider each of these recommendations in more detail.

\section{The Existence and Magnitude of the Crisis}

Individuals or groups actually concerned with a cluster of events may exaggerate the importance and the critical nature of those events as a technique of advocacy or because they have, in good faith, lost perspective. Countless plaintiffs enter court insisting that great and irreparable public and private harm will occur if the court does not immediately grant them the remedy they have requested. And countless courts, drawing on their own well of experience, reject the demand for rapid, comparatively unconsidered decision and move with that deliberate speed which they independently conclude the case at bar warrants. Merely establishing the existence of a crisis is not decisive, for even where events have reached a critical level, rapid decision may not dissipate it. Indeed, in some contexts, an extended period in court may cool things off. The point of emphasis here is that a court, like the citizen importuned by a dazzling salesman to buy something before "it's too late," must determine independently how important speed is and itself act as the architect of the temporal structure of the case.

\section{The Utility of Accelerated Decision}

One of the characteristics of crisis is the high stress to action which it engenders in individuals who see themselves as threatened. This characteristic is potentially dangerous because action itself may neither abate crisis nor cause it to develop in ways congenial to the actor, but may, in fact, exacerbate it. Hence a collegium of judges, like any other group, must ask itself whether the action toward which stress presses it is contextually irrational or will actually contribute to treating the crisis in ways consonant with community goals. To be sure, there are circumstances in which rapid decision can exploit crisis in ways conducive to improved public order, as certain cases of discrimination in the United States have demonstrated. ${ }^{\circ 4}$ Slow, deliberate decision, in contrast, may increase the opportunities to organize resistance to authorized social change. Yet there are many situations in which rapid decision will be a factor of minimum and sometimes negative significance in changing or freezing a situation.

\section{The Costs of Acceleration}

Temporal procedures, as I have said, are designed and refined by practice to maximize the efficiency of decisions and the skill of litigants and court in standardized contexts. Insofar as the procedures actually achieve

64 G. Saenger and E. Gilbert, Customer Reactions to the Integration of Negro Sales Tersonnel, 4 INT'L J. OpINION AND ATtTrUde RESEARCH 57 (1950) and see especially at 69-70. One lesson of these investigations is that in some contexts rapid social change may prove less socially disruptive than slow deliberate change. 
their objectives, variations from them will always have costs, either to the parties or to the court. In a bilateral dispute in which both parties concur in demands for acceleration, the major cost will be borne by the Court, in attenuated opportunities for receipt and processing of information and for deliberation. In bilateral disputes in which one party urges acceleration, the cost will be borne by the other party and by the Court. In cases which are in the character of an actio popularis and invite wide participation or have potentially wide impacts on the community ${ }^{65}$-and these may reach the Court under contentious or advisory jurisdiction-the costs of accelerated procedures will be borne by the Court and all those whose procedural privileges have been comparatively diminished.

It is thus important for a Court petitioned to accelerate its procedures, or contemplating such action, to consider all the costs as against all the benefits which accrue. As the costs increase for the Court and the community, the degree of acceleration which the Court is willing to order should diminish proportionately.

\section{The Special Problem of Constitutional Cases}

Courts make law. All members of the United Nations and all public international organizations are concerned with pending judgments and opinions likely to change or to confirm fundamental aspects of the world constitutive process. ${ }^{68}$ The Statute of the Court emphasizes the special status of such cases by providing rather broad participatory privileges in advisory jurisdiction and more limited opportunities for intervention in the contentious jurisdiction of the Court. ${ }^{87}$ Decisions to accelerate cases of inclusive interests, particularly those of a constitutional character, will have a deprivatory effect on both the Court and many members of the international community. The Court sacrifices more extended opportunities for deliberation; community members lose participatory privileges. Hence, in constitutional cases, judicial resistance to accelerating procedures should increase in proportion to the scope of impact of the projected decision.

\section{The Need for Creative Alternatives}

The costs of acceleration, even when deemed necessary, should move courts to seek alternative and more economic methods of achieving the objectives of acceleration. Speed is of no inherent value. In context, its utility turns on the fact that it may minimize current behavior causing a consumption of values which the Court is likely to characterize as retro-

${ }^{85}$ See generally Schwelb, The Actio Popularis and International Law, IsRAEL YB. HuMaN Rughts 46 (1972).

${ }^{68} \mathrm{McD}$ ougal, Lasswell, and Reisman, The World Constitutive Process of Authoritative Decision, 19 J. Legal Ed. 253, 403; reprinted in 1 BLACK and FalK, The Futune OF THE InTERnationaL LegGAL ORDER 73 (1969).

${ }^{67}$ See Statute Arts. 66 and 62. See also José Puente Egido, Consideraciones sobre la Naturaleza y Efectos de las Opiniones Consultivas 31 ZAöRV 730, 807 (1971) where it is argued that principles of natural justice require broadening jus standi in advisory opinions so that all interested states can participate directly in the proceedings. 
actively unlawful. There are many cases in which this utility can be acquired without acceleration of procedures. The device of interim measures, for example, ${ }^{68}$ may minimize the current consumption of values not by accelerating court procedures, but by decelerating that flow of social events the lawfulness of which the Court is considering. Interim measures would appear to recommend themselves in advisory cases, particularly when many states are concerned with the projected outcome of the case. No authority for interim measures in advisory opinions is given in the Statute. The invention of a functional equivalent is a challenge to judicial ingenuity. One method might be a communication back to the requesting organ, suggesting that it use its own competence to "freeze" events rather than require the Court to accelerate the procedures of the case. ${ }^{69}$

I am, in this respect, critical of the International Court's revision of its rules. ${ }^{70}$ The revisors, apparently much concerned with the need for acceleration of advisory procedures, ${ }^{72}$ felt that the current possibilities for acceleration were inadequate. Hence they have amended Article 87(2) of the Rules to permit the Court to dispense entirely with written evidence and to proceed directly to hearing and deliberation.

When the body authorized by or in accordance with the Charter of the United Nations to request an advisory opinion informs the Court that its request necessitates an urgent answer, or the Court finds that an early answer would be desirable, the Court shall take all necessary steps to accelerate the procedure. If the Court is not sitting when such a request is made, it shall be convened for the purpose of proceeding to a hearing and deliberation on the request.

Judge Jiménez de Aréchaga ${ }^{72}$ explains that authority for this type of acceleration is to be found in the language of Article 66 of the Statute ${ }^{73}$ and in

6s Statute Art. 41. See also Anglo-Iranian Oil Co. case, [1951] ICJ REp. 89; Iceland Fisheries case [1972] ICJ REP. 35.

69 The need for an international injunction process goes far beyond the narrow range of activities of the International Court. Given the capacity of contemporary technology to introduce rapid, vast and perhaps irreparable changes in the environment, the need for an international restraining competence is greater than ever.

${ }^{70}$ For the reasons motivating the Court to depart from its original purpose of systematic revision of the Rules to a partial amendment, see Nuclear Tests Case (Australia v. France), Request for the Indication of Interim Measures of Protection [1973] IC] REP. 99; Jiménez de Aréchaga, supra note 8, at 1 .

71 Id. at 9-11. 72 Id. at 9-10.

${ }^{73}$ Statute Article 66 (4) refers to states which have "presented written or oral statements or both." From this language Judge Jiménez de Aréchaga seems to learn that the Court is authorized to prevent all parties from one of the alternative forms of participation. I would concede that as a general matter of teleological interpretation, the Court may, where appropriate, restrict forms of participation if this does not discriminate in favor of one litigant and contributes to the performance of the major functions of the tribunal. This was the case in the Administrative Tribunals opinion: [1956] ICJ REp. 77. On the other hand, Article 66(4) plainly refers to an option of the states and agencies appearing in the advisory process and not to an option of the Court. The distinction can be important; it distinguishes the Administrative Tribunals case from the regrettable attenuation of participation which the Court has undertaken in its revision of the Rules. On individuals in advisory proceedings, see Gross, Participation of Individuals in Advisory Proceedings Before the International Court of Justice: Question of 
the I.L.O. Administrative Tribunal case. ${ }^{74}$ The language of the Statute is indeed sufficiently general and the I.L.O. Administrative Tribunal case did, in fact, dispense with oral proceedings. The thrust of that decision, however, was not to diminish participation, but to increase it by giving a nonstate litigant effective equality before the Court. Without this device, the Court might have felt constrained to refuse cases of this sort altogether. And though the I.L.O. case had constitutional implications, it was basically an appeal from an international administrative tribunal. There is thus some casuistry in invoking it as a justification for acceleration and concomitant diminution of effective participation. In the same vein, Article 66 of the Statute may be read as a policy instrument for increasing not decreasing participation.

While one can applaud the change in Rule $87(2)$ for increasing the overall Hexibility of the Court and recognize that there will be cases in which time is so decisive that written statements should be dispensed with, one can only regret that this was the sole institutional response which the court could provide to the problem of speed in advisory decisions.

\section{IV}

\section{The Nammian Accederation}

Resolution 2145(XXI) adopted by the General Assembly on October 27, 1966 decided that:

... the Mandate conferred upon His Britanic Majesty to be exercised on his behalf by the Government of the Union of South Africa is therefore terminated, that South Africa has no other right to administer the Territory and that henceforth South West Africa comes under the direct responsibility of the United Nations. ${ }^{75}$

South Africa did not comply with this resolution, claiming it was ultra vires and without legal effect. The Government of South Africa continued to exercise plenary power in the mandated territory and to bar the committee appointed by the General Assembly from entering and undertaking to exercise any authority there. ${ }^{78}$

On January 30, 1970, the Security Council adopted Resolution 276(1970) which recognized the Assembly's termination of the Mandate, considered South Africa's continued presence in Namibia illegal, and concluded by calling upon ". . . the Government of South Africa to immediately withdraw its administration from the territory." 77 On July 29, 1970, the Security Council, recalling Resolution 276, asked the Court for an advisory

Equality Between the Parties, 52 AJIL 16 (1958). And on the real costs of dispensing with oral argument see the dissent of Judge Gros in Application for Review of Judgment No. 158 of the United Nations Administrative Tribunal [1973] ICJ REP. 265-66.

74 [1956] ICJ REP. 77, 85-87.

75 GAOR 21st Sess., Supp. No. 16 (A/6316), at 2.

${ }^{76}$ Report of the United Nations Council for South West Africa, GAOR 22nd Sess., Annexes, Agenda item 64 at 2. Report of the United Nations Council for Namibia, GAOR 23rd Sess., Agenda item 64, A/7338.

77 Sec. Council Res. 276 (1970), Jan. 30, 1970. 
opinion, "at an early date," on the question:

What are the legal consequences for States of the continued presence of South Africa in Namibia, notwithstanding Security Council Resolution 276(1970) ${ }^{78}$

The nominal question posed was the legal consequences for third states of South Africa's continued presence in Namibia. But in responding to this question, the Court could well anticipate that it might (as it indeed did) deal with such fundamental world constitutional questions as its own competence to review the validity of resolutions by the General Assembly and the Security Council, the scope of the prescriptive competence of the General Assembly, and the general competence of United Nations organs to intervene in, modify, and terminate international agreements. Any decision on these matters would have a continuing impact on all members of the global community and the entire institutional structure of decision in international law.

Such questions, one would have thought, would be treated in a tempo of deliberation which would allow as many as possible of the states entitled to participate in the process to have their day in court. Acceleration of proceedings ${ }^{79}$ here would thus be extremely serious and undertaken only for reasons of real urgency. Since the Security Council had only indicated that it wanted an opinion "at an early date" without further specification and since, in any event, the Court must determine the extent of urgency, the President of the Court was presented with a heavy choice.

Unfortunately, neither the majority nor the concurring and dissenting opinions explain why a decision to accelerate was made. The reason was not that the Security Council had suspended all activities and was waiting breathlessly for the Court's opinion. Nor was the reason that the Court's opinion might in any way have alleviated the deprivations of human rights which were then inflicted and continue to be inflicted upon the peoples of Namibia. ${ }^{80}$ The thrust of Security Council Resolution 276 had been to mobilize support among other UN members to act in concert to deny, by word and deed, any recognition of South Africa's effective control over Namibia. The purpose of Security Council Resolution 284 was to determine the "legal consequences" for third states of South Africa's continued presence in Namibia. No one in the General Assembly, the Security Coun-

78 Sec. Council Res. 284 (1970), July 29, 1970.

70 The Permanent Court dispensed with oral argument in the interim measures phase of the Belgian-Chinese case, PCIJ ser. A, No. 8, at 6-8 (1927) perhaps because China appointed no agent and at no time made an appearance. It also dispensed with them in the Prince von Pless case, ser. A/B, No. 54, at 150, 152 after waiver of "the right to a hearing" by each side. On the advisory side, there were no oral arguments in the Polish Postal Service case, PCIJ ser. B, No. 11, at 10. In the Jurisdiction of Danzig Courts case, PCIJ ser. B, No. 15, at 7, the Permanent Court insisted on argument despite the disinterest of the "interested states." In the interim measures phase of Chorzow Factory case, ser. A, No. 12, at 9 (1927), the Court dispensed with observations by Poland, in effect the respondent, because it rejected virtually in limine litis, Germany's request.

80 For a survey of the literature in this regard, see S. Gross, The United Nations, Self-Determination and the Namibia Question, 82 YALE L.J. 533 (1973). 
cil, or the Court believed for a moment that any decision in this advisory procedure would lead to an abrupt change of South African policy, much less a sudden withdrawal from Namibia. Given these conditions, acceleration involved costs but no gains.

The reasons for the Security Council's request for acceleration and the intensity of the demand for urgency are unavailable. Speaking speculatively, as one must, it seems that the Court acceded to the request to accelerate the procedure because it was conscious of criticism that its proceedings (notably in the Barcelona Traction Co. case) had been too lengthy and slow moving and because changes in the composition of the Court had brought to the fore a coalition which believed that the 1966 contentious decision was incorrect and had harmed the image of the international judiciary. ${ }^{81}$ The 1970 request was a chance to correct that image and to regain credentials of justice among a majority of the states of the world. And indeed, the Court may have succeeded in this objective. Parts of the substantive portion of its opinion of June 21, 1971 may prove to be a most important contribution to world order. But a judicial urge to regain respect can hardly justify an accelerated procedure diminishing the privileges of participation.

There is, of course, a constant pressure internationally and nationally to bend procedural forms to the larger issue on which the action is brought. After all, it would seem, procedure is an instrument for the substantive issue and not vice versa. In Robinson $v$. Smyth, ${ }^{82}$ an old case which bears some eerie resemblances to the Namibia case, the plaintiff, a seaman, sued for wages for a voyage from the West Indies to London. The defense was that the plaintiff was a slave for whom the defendant had paid valuable consideration. But this could only be established by an absent witness. Accordingly, the defendant moved to put off the trial until the witness was available. The Court of Common Pleas rejected the motion, on the ground that the entire defense was "odious" and should be given no assistance by the court.

In Robinson v. Smyth, the Court of Common Pleas was using procedure as a way of terminating an undesirable institution. But the Court itself would not have dismissed the importance of procedure, for procedures themselves are expressions of important community policies. If a court is concerned with its image of due process, the Robinson v. Smyth technique can only be used if, first, there has been some prior public deliberation about the justice of the institution in question. If there has not been such deliberation, one party is really being deprived of a chance to present its position and its conception of the common interest and to have it deliberated. Second, there must be effective political power at the disposal of the court in question to back up its pronouncement or, at least, to have

81 Of the six regular members of the Court voting for the 1966 judgment, only Judges Fitzmaurice and Gros remained for the 1971 Opinion. For a critique of the judgment and an argument for its nullification on grounds of improper composition, see Reisman, Revision of the South West Africa Cases, supra note 29, at 3.

82 I Bos. \& Pul. 455 (1799); 126 E.R. 1007. 
it accepted as authoritative. Any legislator without effective power will not make law for others, but will make a fool of himself. Third, the technique can only be used, in a manifest way, sparingly; if it is used more, the promise of due process, which is a distinctive attraction of judicial institutions, will be squandered.

\section{$\mathrm{V}$}

\section{Alternattves for the Future}

Where time is of the essence, a number of institutional devices may be adapted or invented in order to achieve the benefits of acceleration with a minimum of the costs we have assessed. Let us consider these alternatives, starting with the least ambitious.

1. Where there is an accelerated procedure, the Registrar should not leave The Hague for extended periods of time, for his advice to participants and to the President of the Court can alleviate many of the hardships of accelerated procedure. In the Namibia case, the critical temporal period extended from the first week of August to November 19, 1970. The Registrar was engaged in what he characterized as a "somewhat prolonged visit" at UN headquarters from the second week of September until early November $1970 .{ }^{83}$

2. In accelerated procedures, the Court should designate the Secretary-General as an authorized alternative receipt agent for certified documents, or have someone in the Secretariat designated as a second deputy Registrar (in addition to the one in The Hague). The Secretary-General would transmit the documents by courier upon receipt and the Registry of the Court would deem them received the moment they were deposited with the Secretary-General. The effectiveness of this suggestion will depend, of course, on the international civil servant in question performing his function with dispatch. In the Namibia case, mail between New York and The Hague seemed regularly to take five days! Where a particular region is concerned in an advisory case, an official of a regional organization might be designated as receipt agent for that case.

3. If time is of the essence and the Court decides to accelerate litigation, it should make a comparable effort to accelerate its own internal procedures. With the exception of the I.L.O. case, ${ }^{8 *}$ in many ways a special species of international administrative appeal handled throughout at a most leisurely pace, the ICJ in the Namibia case took almost twice as much time from closure of all proceedings to the delivery of the opinion as it had taken, on the average, in other advisory opinions. The simplest device for acceleration involves a per curiam decision of the dispositif which is made public as soon as possible. It is then followed by a separate presen-

${ }^{83}$ Letter from Registrar, Nov. 6, 1970, 2 Pleadings 638.

84 Judgment of the Administrative Tribunal of the International Labor Organization upon Complaints Made Against the UNESCO, [1956] ICJ REP. 77. 
tation of the entire opinion, including the concurring and dissenting opinions, at a later date. ${ }^{85}$

4. An accelerated procedure should not attempt to dispense with written statements in favor of oral argument alone, although it should limit their length. The tendency of the Court in the Namibia case and in its revision of some of its Rules ${ }^{88}$ has been to sacrifice written statements when an accelerated procedure is deemed necessary. To be sure the express language of Article 66 of the Statute of the Court is disjunctive and not mandatorily cumulative; the reference there is to written or oral statements "or both." Judge Guerrero, moreover, did argue, as Judge Jiménez de Aréchaga notes, in the course of the drafting of the Rules of Court of the Permanent Court of International Justice that the Court "was not bound to arrange both for written and oral proceedings." 87 And indeed where urgency of decision is paramount, it may be necessary to dispense with the written statements. But this should be a last resort for a number of reasons. First, written statements permit a considered presentation of issues. Second, and extremely important, written statements permit organizations and perhaps ultimately nongovernmental organizations to participate in advisory proceedings in which they can contribute data relevant to the decision at bar. ${ }^{88}$ Third, submission and processing of a written statement actually takes less court time than does oral argument, for reading a text is faster than listening to it in its interpreted duplicate in the laborious pleading pattern of the International Court of Justice. Where time is of the essence, written statements should be limited but not dropped completely. The Court may indicate that it does not wish statements of more than, let us say, thirty pages ${ }^{80}$ or indicate the points on which it wishes to hear argument.

85 This would have been quite feasible in the Namibia case itself. The great bulk of the majority opinion there deals with preliminary questions, subjected to exhaustive legal analysis. It is only in paragraph 117 (page 42 of a 46 page opinion) that the majority states: "Having reached these conclusions, the Court will now address itself to the legal consequences arising for States from the continued presence of South Africa in Namibia. . . " Thereafter, the dispositif is presented in one and a half pages.

86 See text and notes supra at 18-19.

87 Jiménez de Aréchaga, supra note 8, at 10. If the context of Judge Guerrero's comment is taken into account, its import is changed. The discussion revolved about a proposal submitted by Judge Negulesco to permit oral argument in advisory opinions which were about "questions" and not about "disputes." The proposal was withdrawn and the consensus seems to have been that the rule change would have been ultra vires Statute Article 66, PCIJ, ser. D. Acts and Documents Concerning the Organization of the Court; Third Addendum to No. 2. Elaboration of the Rules of Court of March 11th, 1936.

88 Statute Art. 66, paras. 2 and 4. Cf. Art. 34 (3).

89 In a companion article to this study, [Amici Curiae Jure Gentium: For a Court in Need of Friends (in preparation)], I argue that the major motive for the Court's attenuation of the privilege of submission of written statements may have been to limit the amount of data which it would have to process in cases and, more generally, to limit "excessive" participation in the case. It is ironic that Judge Jimenez de Arechaga in his defense of the revised Rules of Court cited the I.L.O. case as a precedent for dropping written pleadings. In the I.L.O. case, oral argument was dropped to increase participation on equal terms. The Court accepted the written statements of both the 
5. Some minor changes in the Statute and the Rules might be considered to enable the Court to exploit its existing institutional arrangements more effectively. In accelerated procedures, the President of the Court should immediately convoke the chamber of summary procedure ${ }^{90}$ as soon as he has provisionally characterized the case as one of an urgent nature. Precisely because accelerated procedure does involve judicial costs and diminution of the procedural privileges of some and in some cases of all litigants concerned, it should have collegiate judicial consideration before it is so characterized. While events may dictate a rather rapid in camera decision, it is conceivable that short notice might be given to interested parties to appear for oral argument and to show cause why the accelerated procedure should not be resorted to. If the chamber of summary procedure concludes that the requested opinion warrants acceleration, the chamber should remain in continuous session until the plenary court is convened or oral argument commences. Rulings by the President that deny the procedural privileges of one or more litigants would be appealed to the chamber which would rule after hearing oral argument.

6. Some functional equivalent to the injunction or "indication of interim measures" should be developed for advisory opinions. When the Court is asked to speed up, it should have the competence to turn and ask others to slow down. Ingenuity will be required to implement this device.

I would propose the following procedures: the chamber of summary procedure, upon determining that the urgency of the case at bar warrants commencing an accelerated procedure, would proceed to draft an advisory opinion on interim measures, the purpose of which would be to prevent acts and events that might frustrate or impede the advisory deliberations. This interim opinion would be delivered to the organization requesting the advisory opinion with the request that the petitioning organ give the interim opinion its earliest attention. Depending upon the urgency of the situation, the organ could then either require or recommend to its own members that they comply with the interim request of the Court. Because the Court would be considering the merits of the case immediately thereafter and because the good faith of some states might be of some relevance to the Court's deliberations and formulation of an opinion, the interim opinion could actually have more potential as a sanction than the final opinion itself.

I.L.O. and a private party and dispensed with oral argument for it assumed that only the I.L.O. would have been permitted to appear in that phase. The Court might also have permitted the employees and the I.L.O. to argue orally as two representatives of the I.L.O. appearing on behalf of that organization. I believe that attenuation of participation is unwise as a political strategy and ill-considered as a technique for increasing the rationality of judicial decision. Currently the device of the written statement is the most economic way of increasing participation in advisory and ultimately perhaps in contentious jurisdiction.

go See note and text supra at note 9. Significantly, the revised rules do attempt to expand the role of Chambers. See Jessup, To Form a More Perfect United Nations, 129 RECUEn, DES Couns 21 (1970); Hyde, A Special Chamber of the International Court of Justice, 62 AJIL 439 (1968); Jiménez de Aréchaga, supra note 8, at 2-4. 


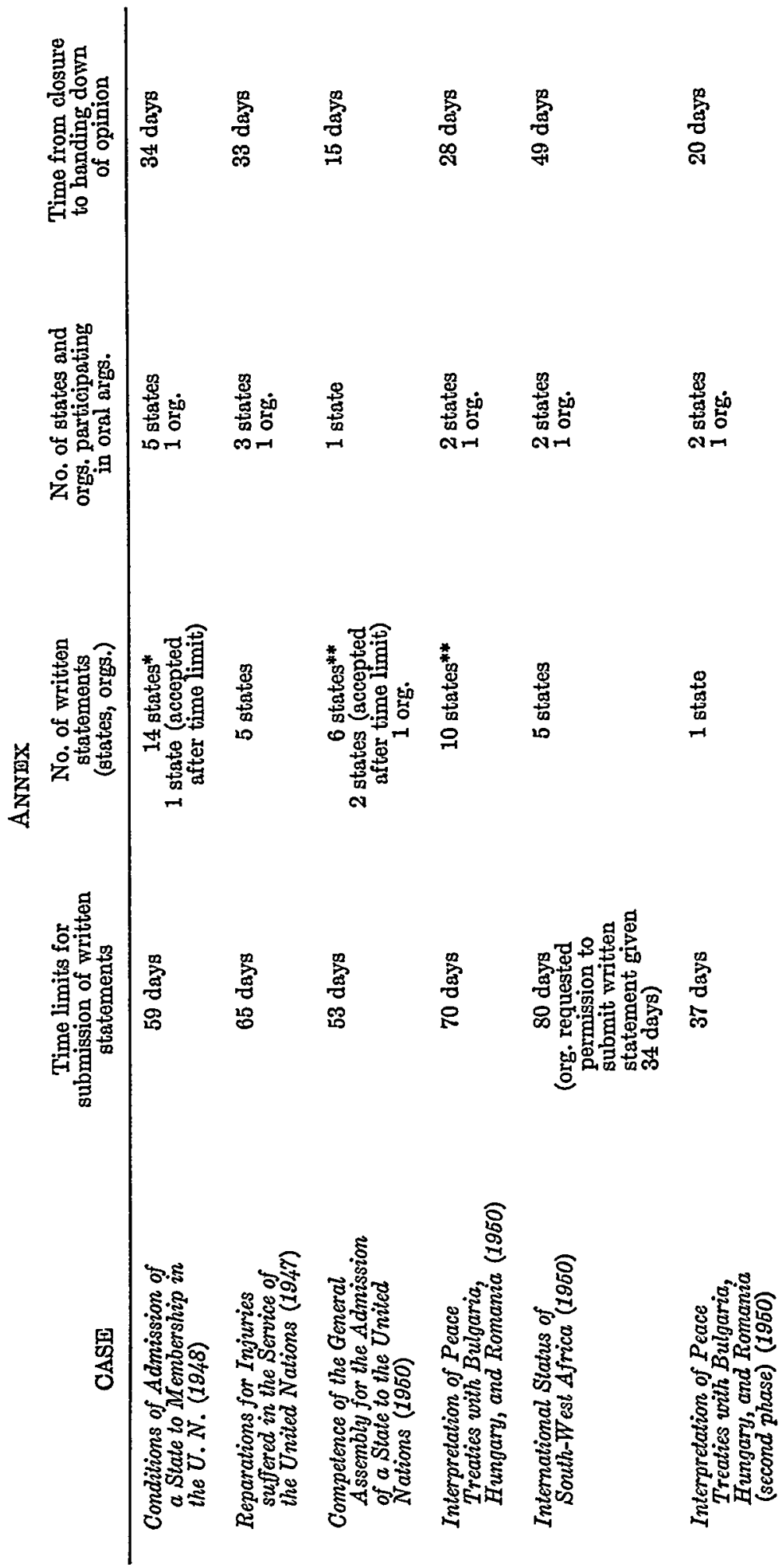




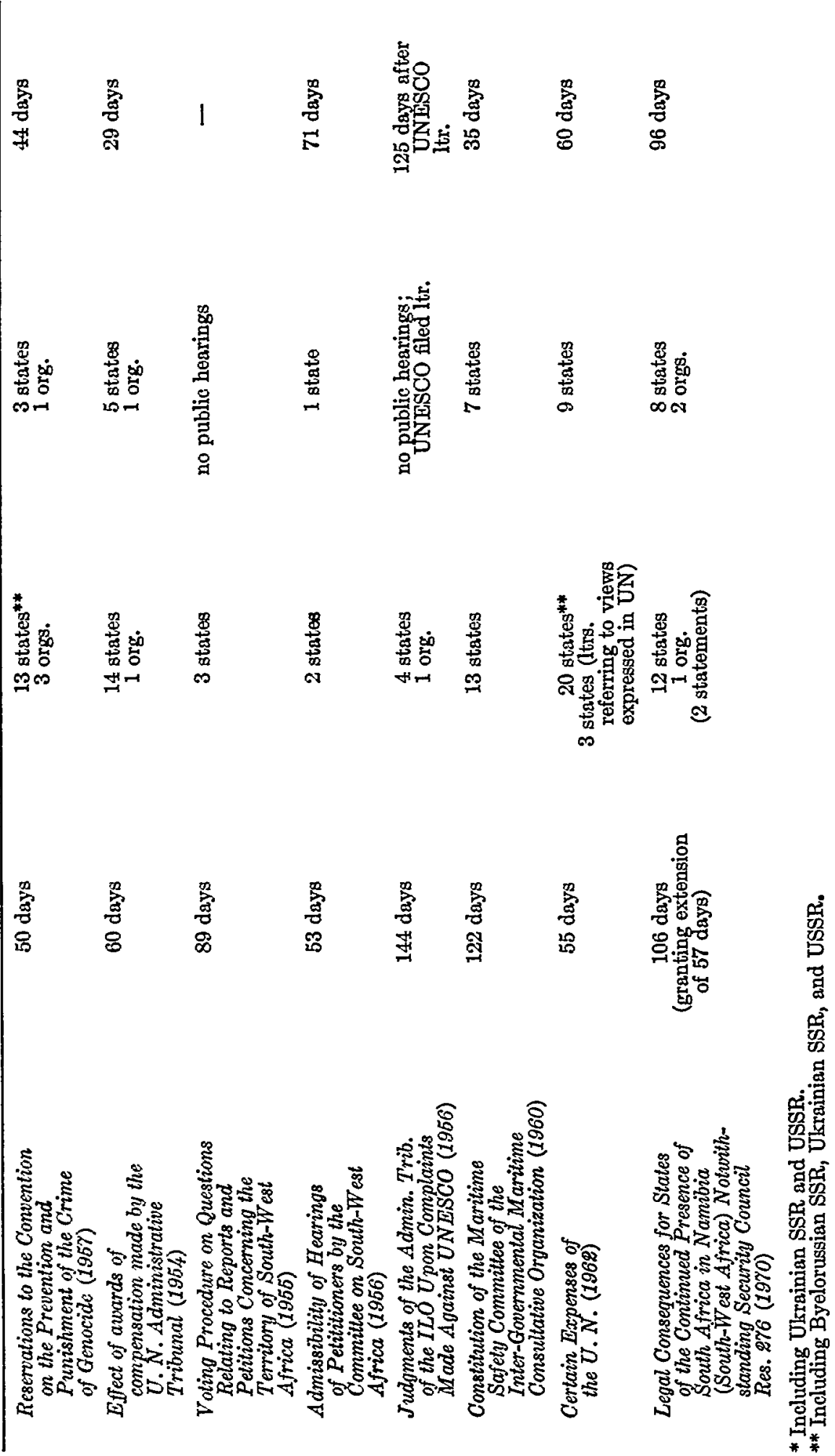

